\title{
Faktor-Faktor yang Berhubungan dengan Konsumsi Sayur dan Buah pada Siswa Sekolah Dasar
}

\author{
Factors Related to Consumption of Vegetables and Fruits \\ in Elementary School Students
}

\author{
Mindo Lupiana $^{1, \bowtie}$, Sadiman Sadiman $^{2}$ \\ ${ }^{1}$ Jurusan Gizi, Poltekkes Kemenkes Tanjung Karang, Indonesia \\ ${ }^{2}$ Jurusan Kebidanan, Poltekkes Kemenkes Tanjung Karang, Indonesia \\ ${ }^{\bowtie}$ Corresponding author: mindo_lupiana@yahoo.com
}

\begin{abstract}
Kata kunci:
Konsumsi buah,

konsumsi sayur,

Sikap,

Pengetahuan.
\end{abstract}

Keyword:

Fruit consumption,

Vegetable consumption,

Attitude,

Knowledge.

\begin{abstract}
Abstrak
Latar Belakang: Konsumsi buah masyarakat Indonesia masih relatif rendah dibandingkan negara lain yang tidak memiliki sumber daya sebagai penghasil buah-buahan. Tujuan: penelitian ini adalah untuk mengetahui faktor-faktor yang berhubungan dengan konsumsi buah dan sayur pada siswa Sekolah Dasar. Metode: Metode penelitian ini menggunakan rancangan cross sectional. Populasi penelitiaan ini adalah seluruh siswa kelas V berjumlah 123 siswa dan sampel penelitian berjumlah 100 siswa yang ditentukan dengan menggunakan simple random sampling. Penelitian ini dilakukan di Negeri 1 Rajabasa Raya Kota Bandar Lampung. Pengolahan data pada penelitian ini dalam univariat dan bivariat menggunakan uji chi square. Hasil: Hasil penelitian menunjukkan bahwa faktor yang berhubungan dengan konsumsi buah dan sayur adalah preferensi $(\mathrm{p}=0,001)$, pengetahuan $(\mathrm{p}=0,000)$ dan sikap $(\mathrm{p}=000)$. Variabel yang tidak berhubungan yaitu ketersediaan di rumah $(\mathrm{p}=0,813)$. Simpulan: Faktor yang meningkatkan konsumsi buah dan sayur pada siswa Sekolah dasar adalah preferensi, pengetahuan yang baik, dan sikap yang mendukung. Perlu dilakukan sosialisasi untuk meningkatkan pengetahuan tentang manfaat dan dampak kurang konsumsi buah dan sayur, memasang media poster tentang manfaaat dan dampak kurang konsumsi buah dan sayur.
\end{abstract}

\begin{abstract}
Background: Indonesian people's fruit consumption is still relatively low compared to other countries that do not have the resources to produce fruits. Purpose: this study was to determine the factors associated with fruit and vegetable consumption in elementary school students. Methods: This research method uses a cross sectional design. The research population was all students in class $V$ totaling 123 students and the study sample was 100 students who were determined using simple random sampling. This research was conducted in Negeri 1 Rajabasa Raya Bandar Lampung City. Data processing in this study was univariate and bivariate using the chi square test. Results: The results showed that the factors associated with fruit and vegetable consumption were preference $(p=0.001)$, knowledge $(p=0,000)$ and attitude $(p=000)$. The unrelated variable is the availability at home ( $p=$ 0.813). Conclusion: Factors that increase consumption of fruit and vegetables in elementary school students are preference, good knowledge, and supportive attitude. Socialization needs to be done to increase knowledge about the benefits and effects of less consumption of fruit and vegetables, put up a poster media about the benefits and effects of less consumption of fruits and vegetables.
\end{abstract}

Copyright ${ }^{(0)} 2017$ Jurnal Kesehatan Metro Sai Wawai. All rights reserved. 


\section{Pendahuluan}

Pentingnya bahan makanan bagi tubuh membuat seseorang harus benar-benar memperhatikan pola makan sehari-hari agar tetap sehat dan terhindar dari berbagai macam penyakit. Buah dan sayuran sangat penting sebagai sumber nutrisi yang dibutuhkan oleh tubuh manusia. Berdasarkan gizi seimbang, penduduk Indonesia dianjurkan mengkonsumsi buah sebanyak 2-4 porsi dan sayur-sayuran 3-5 porsi dalam sehari. Konsumsi buah dan sayur yang dianjurkan yaitu sebanyak 200-300 gram buah dan 150-200 gram sayur dalam sehari (Almatsier, 2011).

Kurang konsumsi buah dan sayur dapat menimbulkan berbagai dampak antara lain dapat menurunkan imunitas atau kekebalan tubuh seperti mudah terkena influensae, mudah mengalami stres atau depresi, tekanan darah tinggi, gangguan pencernaan seperti sembelit, gusi berdarah, sariawan, gangguan pada mata, kulit menjadi keriput, arthritis, osteoporosis, jerawat, kelebihan kolesterol darah dan kanker (Akhmad, 2011). Konsumsi buah dan sayur yang berbeda akan memberikan dampak yang berbeda pada risiko kanker kolon proksimal, usus besar distal dan rektum (Annema et al, 2011).

Berdasarkan research WHO (2013) penyakit tidak menular yaitu penyakit kardiovaskular (seperti serangan jantung dan stroke), kanker, penyakit pernapasan kronis (seperti penyakit paru obstruksi kronis dan asma) dan diabetes menjadi penyebab tingginya angka kematian di dunia sebesar $80 \%$ terutama pada negara-negara yang berpenghasilan rendah. Sekitar 1,7 juta kematian tersebut disebabkan oleh konsumsi buah dan sayur yang rendah.

Konsumsi buah masyarakat Indonesia masih relatif rendah dibandingkan negara lain yang tidak memiliki sumber daya sebagai penghasil buah-buahan. Menurut hasil survei Badan Pusat Statistik (BPS) rata-rata konsumsi buah per kapita dalam sehari masyarakat Indonesia pada tahun 2011 sebesar 45,8\%. Konsumsi buah pada tahun 2012 hanya mengkonsumsi 45\% sesuai anjuran. Rata-rata konsumsi buah menurun pada tahun 2013 hanya sebesar 44,56\% mengkonsumsi sesuai anjuran. Konsumsi sayur-sayuran masyarakat Indonesia pada tahun 2011 sebesar 37,46\%. Konsumsi sayuran pada tahun 2012 yaitu 37,72\%, sedangkan konsumsi sayuran menurun pada tahun 2013 yaitu sebesar $34,96 \%$ (BPS, 2013).

Mengkonsumsi buah dan sayur berdasarkan rekomendasi WHO dan FAO yaitu sebanyak 400 gram setiap hari atau sebanyak 3-5 porsi buah dan sayur dalam sehari (WHO dan FAO, 2004). Rekomendasi Dietary Guidelines for America untuk mengkonsumsi buah dan sayur yaitu minimal 5 porsi dalam sehari. Berdasarkan gizi seimbang, penduduk Indonesia dianjurkan mengkonsumsi buah sebanyak 2-4 porsi dan sayur-sayuran 3-5 porsi dalam sehari (Astawan dan Andreas, 2008). Konsumsi buah dan sayur yang dianjurkan yaitu sebanyak 200-300 gram buah dan 150-200 gram sayur dalam sehari (Almatsier, 2011).

Anak usia sekolah merupakan salah satu kelompok rawan gizi yang perlu mendapatkan perhatian. Mereka merupakan cikal bakal sumberdaya manusia sehingga perlu diperhatikan asupan gizinya sehingga mereka dapat tumbuh dan berkembang menjadi sumber daya manusia yang berkualitas. Anak sekolah memerlukan asupan energi dan zat gizi seperti protein, kalsium, seng, besi, vitamin dan serat. Konsumsi buah dan sayur pada remaja sangat penting untuk menjaga kadar serum vitamin $\mathrm{C}$ dan pemenuhan kebutuhan asam folat yang cukup tinggi dalam tubuhnya selama masa pertumbuhan dan perkembangan (Arisman, 2008).

Anak sekolah cenderung memiliki perilaku makan yang tidak stabil karena pada masih dipengaruhi keluarga dan pengaruh teman. Kebiasaan makan pada anak usia sekolah dipertahankan hingga usia dewasa. Sehingga perilaku makan yang buruk pada masa usia sekolah memberikan dampak seumur hidupnya (Klepp et al, 2005).

Berdasar uraian di atas betapa pentingnya konsumsi buah dan sayur terutama pada masa terjadi pertumbuhan dan perkembangan membutuhkan banyak asupan zat gizi. Konsumsi buah dan sayur kalangan remaja masih kurang. Artikel ini memberikan informasi faktor-faktor yang 
berhubungan dengan konsumsi buah dan sayur pada anak sekolah. Pemilih tempat penelitian SD Negeri 1 Rajabasa Raya yang terletak di Kecamatan Rajabasa, yang merupakan daerah pinggiran yang berbatasan dengan kabupaten Lampung Selatan.

\section{Metode}

Penelitian yang dilakukan bersifat deskriptif analitik dengan menggunakan rancangan penelitian cross sectional. Populasi penelitian adalah siswa kelas V SD yang berjumlah 123 orang. Sampel penelitian sebanyak 100 orang yang diambil dengan tehnik simple random sampling. Alasan diambilnya kelas V karena sudah dapat memahami dan menjawab kuesiner dengan baik. Lokasi penelitian di SDN 1 Rajabasa Raya Bandar Lampung dan waktu pengambilan data dilakukan pada bulan Oktober tahun 2015. Pengumpulan data dilakukan dengan wawancara terstruktur dengan menggunakan kuesioner. Variabel dependen adalah konsumsi sayur dan buah. Variabel independen adalah prerefensi (kesukaan), ketersediaaan, pengetahuan dan sikap.

Analisis data penelitian secara univariat dan bivariat. Untuk mengetahui hubungan variabel digunakan analisis bivariat dengan chi square karena variabel independen dan dependen merupakan data kategorik (Hastono, 2001).

\section{Hasil}

\section{Gambaran variabel Penelitian}

Hasil univariat pada penelitian ini untuk melihat distribusi konsumsi sayur dan buah, preferensi, ketersediaan, pengetahuan dan sikap terhadap konsumsi sayur dan buah. Konsumsi sayur dan buah adalah sayur dan buah yang dikonsumsi sesuai anjuran yaitu masing-masing sebanyak 200 gram per hari (Almatsier, 2011). Pada penelitian ini konsumsi buah dan sayur dikelompokkan menjadi dua kategori yaitu kurang dan baik. Kategori konsumsi buah dan sayur kurang apabila jumlah konsumsi buah $<200$ gram per hari dan konsumsi sayur < 200 gram per hari dan baik apabila jumlah konsumsi buah $\geq 200$ gram per hari dan konsumsi sayur $\geq 200$ gram per hari.

Tabel 1 memperlihatkan bahwa siswa yang kurang mengkonsumsi sayur dan buah sebanyak $43 \%$, mempunyai preferensi yang kurang terhadap konsumsi sayur dan buah sebanyak 52\%, Ketersediaan sayur dan buah di rumah dalam kategori negatif sebanyak $44 \%$. Siswa yang mempunyai pengetahuan yang kurang terhadap manfaat dan dampak dari mengkonsumsi sayur dan buah sebanyak $26 \%$. Siswa yang mempunyai sikap yang kurang baik terhadap konsumsi sayur dan buah sebanyak $41 \%$.

\section{Tabel 1}

Distribusi konsumsi sayur dan buah, preferensi, ketersediaan, pengetahuan dan sikap terhadap buah dan sayur pada Siswa Sekolah Dasar di SD Negeri 1 Rajabasa Raya

\begin{tabular}{llcc}
\hline Variabel Penelitian & Kategorik & Jumlah $(\mathbf{n}=\mathbf{1 0 0})$ & Persentase (\%) \\
\hline Konsumsi Sayur dan Buah & Kurang & 43 & 43 \\
\multirow{3}{*}{ Preferensi } & Baik & 57 & 57 \\
\multirow{3}{*}{ Ketersediaan di rumah } & Kurang & 52 & 52 \\
& Baik & 48 & 48 \\
Pengetahuan & Negatif & 44 & 44 \\
\multirow{3}{*}{ Sikap } & Positif & 56 & 56 \\
& Kurang & 60 & 60 \\
& Baik & 14 & 14 \\
& Kurang & 41 & 41 \\
\hline
\end{tabular}




\section{Analisis Bivariat}

Hasil uji statistik yang meliputi preverensi, Ketersediaan, pengetahuan dan sikap dengan konsumsi sayur dan buah seperti terlihat pada tabel 2. Hasil analisis bivariat dengan uji chi square untuk mengetahui hubungan preferensi (kesukaan), ketersediaan, pengetahuan dan sikap terhadap konsumsi sayur dan buah. Variabel yang ada hubungan secara bermakna dengan konsumsi sayur dan buah meliputi: preferensi dengan nilai $\mathrm{p}=0,001$, pengetahuan dengan nipai $\mathrm{p}=0,000$ dan sikap siswa terhadap dengan nilai $\mathrm{p}=0,000$. Sedangkan, variabel yang tidak ada hubungan yang bermakna dengan konsumsi sayur dan buah adalah ketersediaan sayur dan buah di rumah dengan nilai $\mathrm{p}=0,813$.

Tabel 2.

Distribusi Preverensi, Ketersediaan, Pengetahuan dan Sikap dengan Konsumsi Sayur dan Buah

\begin{tabular}{|c|c|c|c|c|c|c|c|}
\hline \multirow[t]{3}{*}{ Variabel } & \multicolumn{4}{|c|}{ Konsumsi Sayur dan Buah } & & & \multirow[b]{3}{*}{$\mathrm{p}$-value } \\
\hline & \multicolumn{2}{|c|}{ Kurang } & \multicolumn{2}{|c|}{ Baik } & \multicolumn{2}{|c|}{ Jumlah } & \\
\hline & $\mathrm{N}$ & $\%$ & $\mathrm{n}$ & $\%$ & $\mathrm{n}$ & $\%$ & \\
\hline \multicolumn{8}{|l|}{ Preferensi } \\
\hline Kurang & 31 & 59,6 & 32 & 40,4 & 52 & 100 & 0,001 \\
\hline Baik & 12 & 25,0 & 36 & 75,0 & 48 & 100 & \\
\hline \multicolumn{8}{|c|}{ Ketersediaan } \\
\hline Negatif & 20 & 45,5 & 24 & 54,5 & 44 & 100 & 0,813 \\
\hline Positif & 23 & 41,1 & 33 & 58,9 & 56 & 100 & \\
\hline \multicolumn{8}{|c|}{ Pengetahuan } \\
\hline Kurang & 25 & 96,2 & 1 & 3,8 & 26 & 100 & 0,000 \\
\hline Sedang & 15 & 25,0 & 45 & 75,0 & 60 & 100 & \\
\hline Baik & 3 & 21,4 & 11 & 78,6 & 14 & 100 & \\
\hline \multicolumn{8}{|l|}{ Sikap } \\
\hline Kurang & 27 & 65,9 & 14 & 34,1 & 41 & 100 & \\
\hline Baik & 16 & 27,1 & 43 & 72,9 & 59 & 100 & 0,000 \\
\hline
\end{tabular}

\section{Pembahasan}

\section{Konsumsi sayur dan buah pada siswa SD}

Konsumsi sayur dan buah yang kurang sangat penting dalam memenuhi kebutuhan zat gizi untuk menunjang pertumbuhan dan perkembangan tubuh. Sayur dan buah yang kurang merupakan sumber vitamin dan mineral sehingga kekurangan konsumsi berpengaruh terhadap kondisi gizi yaitu dapat menurunkan imunitas tubuh seperti mudah terkena flu, mengalami stres, tekanan darah tinggi, gangguan pencernaan, gusi berdarah, sariawan, gangguan pada mata, kulit menjadi keriput, arthritis, osteoporosis, jerawat, kelebihan kolesterol darah dan kanker (Akhmad, 2011). Selain itu dapat menyebabkan kurangnya darah (anemia), memicu timbulnya kanker dan menjadi 10 besar faktor penyebab kematian di dunia karena kurangnya konsumsi buah dan sayur menyebabkan kurangnya asupan serat yang dapat menimbulkan berbagai penyakit, (Khomsan, 2003).

Penelitian yang dilakukan Farida (2007) di Indonesia tentang faktor-faktor yang berhubungan dengan perilaku konsumsi buah dan sayur pada remaja Indonesia menunjukkan bahwa sebagian besar remaja memiliki perilaku konsumsi buah dan sayur yang kurang yaitu 94,5\% dan 5,5\% memiliki perilaku konsumsi buah dan sayur dengan kategori baik.

Konsumsi sayur dan buah pada siswa dapat dipengaruhi oleh perubahan pola konsumsi pada hampir semua provinsi di Indonesia. Saat ini orang cenderung mengkonsumsi makanan serba instan dan praktis menyebabkan rendahnya konsumsi sayur dan buah pada masyarakat. Konsumsi sayur dan buah juga dapat dipengaruhi oleh lingkungan tempat tinggal. Penduduk yang tinggal di kota lebih 
mencukupi porsi mengkonsumsi sayur dan buah dibandingkan penduduk yang tinggal di desa. Hasil Riskesdas tahun 2007 di Lampung menunjukkan bahwa penduduk kota mengkonsumsi sayur dan buah dengan kategori cukup sebanyak 12,8\% sedangkan penduduk di desa yang mengkonsumsi sayur dan buah dengan kategori cukup yaitu sebesar 9,3\% (Balitbangkes, 2008).

\section{Hubungan preferensi (kesukaan) dengan konsumsi sayur dan buah}

Preferensi terhadap makanan menentukan konsumsi terhadap makanan tertentu dan arti makanan bagi individu. Berdasarkan hasil analisis univariat diketahui bahwa siswa dengan preferensi kurang terhadap sayur dan buah lebih sedikit yaitu 52\% dan hasil analisis diketahui bahwa ada hubungan yang signifikan antara preserensi (kesukaan) dengan konsumsi sayur dan buah pada siswa SD Negeri 1 Rababasa Raya yang ditunjukkan dengan nilai $\mathrm{p}=0,001$.

Preferensi terhadap sayur dan buah pada siswa SD Negeri 1 Rajabasa Raya berhubungan terhadap konsumsi sayur dan buah. Tetapi masih banyak siswa yang yang kurang suka mengkonsumsi sayur dan buah (48\%). Siswa yang memiliki preferensi kurang sayur dan buah karena rasannya yang sedikit masir. Dibandingkan buah, siswa lebih tidak menyukai sayur terutama pada sayur yang rasanya tidak enak dan tidak menarik. Konsumsi sayur dan buah yang kurang pada siswa dapat ditingkatkan terutama jika siswa memiliki preferensi kurang terhadap sayur dan buah. Siswa dapat melakukan pemilihan sendiri terhadap bahan makanan yang mereka suka terutama sayur dan buah yang mereka suka. Sehingga, konsumsi siswa terhadap sayur dan buah dapat meningkat.

Salah satu faktor yang dapat mempengaruhi tingkat konsumsi seseorang adalah kesukaan dan preferensi makanan yang dapat dipelajari dan diubah sejak kecil. Kesukaan individu terhadap makanan tertentu menjadi faktor penentu dalam memilih makanan termasuk sayur dan buah. Rasa makanan yang tidak enak tetapi penampilannya menarik, individu akan cenderung menyukainya dibandingkan makanan yang kurang enak dan penampilannya tidak menarik (Geissler dan Power, 2010). Hasil penelitian Klepp et al (2005) di Eropa tentang promosi konsumsi buah dan sayur antara anak sekolah di Eropa yang menunjukkan bahwa preferensi (kesukaan) terhadap buah dan sayur berpengaruh dalam meningkatkan konsumsi buah dan sayur seseorang.

Preferensi (kesukaan) siswa terhadap sayur dan buah dipengaruhi oleh rasa, penampilan, tekstur dan aroma dari sayur dan buah. Banyak dari siswa yang tidak menyukai sayur dan buah karena penampilan yang kurang menarik dan rasanya yang tidak enak. Sehingga, perlu dibuat olahan dari buah dan sayur agar siswa dapat menyukai rasa dan penampilan dari buah maupun sayur dan konsumsi siswa

\section{Hubungan ketersediaan sayur dan buah di rumah}

Ketersediaan sayur dan buah di rumah merupakan sayur dan buah yang tersedia di rumah baik yang berasal dari membeli atau tidak. Ketersediaan sayur dan buah di rumah adalah faktor lingkungan yang mempengaruhi konsumsi sayur dan buah seseorang.

Hasil analisis menunjukkan bahwa konsumsi sayur dan buah pada siswa yang memiliki ketersediaan sayur dan buah yang negatif maupun yang positif di rumah memiliki konsumsi yang tidak jauh berbeda. Hasil analisis bivariat diketahui bahwa tidak ada hubungan yang bermakna antara ketersediaan sayur dan buah di rumah terhadap konsumsi sayur dan buah pada siswa SD Negeri 1 Rajabasa Raya tahun 2015 yang ditunjukkan dengan nilai $\mathrm{p}=0,813$ ( $\mathrm{p}>0,05)$.

Penelitian Farisa (2012) pada siswa SMPN 8 Depok menunjukkan bahwa ada hubungan yang bermakna antara ketersediaaan di rumah dengan konsumsi sayur dan buah dan ketersediaan sayur dan buah yang kurang baik di rumah memiliki peluang 4,5 kali lebih besar untuk kurang konsumsi sayur dan buah dibandingkan yang ketersediaan di rumahnya baik. Hal ini sesuai dengan Sanvick et al (2005) yang menyatakan bahwa ketersediaan sayur dan buah di rumah berhubungan positif dengan 
konsumsi sayur dan buah. Sehingga, ketersediaan sayur dan buah yang baik di rumah berpengaruh baik terhadap konsumsi sayur dan buah.

Kebiasaan konsumsi sayur dan buah disebabkan berbagai faktor. Tidak hanya ketersediaan saja, tetapi kesukaan (preferensi), pengetahuan, kebiasaaan dalam keluarga dan budaya masyarakat memberi dampak juga.

\section{Hubungan pengetahuan dengan konsumsi sayur dan buah}

Klepp et al (2005) menempatkan pengetahuan sebagai faktor individu yang mempengaruhi tingkat konsumsi sayur dan buah pada remaja. Hasil analisis bivariat diketahui bahwa ada hubungan yang signifikan antara pengetahuan tentang sayur dan buah terhadap konsumsi sayur dan buah pada siswa SD Negeri 1 Rajabasa Raya Kota Bandar Lampung tahun 2015 yang ditunjukkan dengan nilai $\mathrm{p}=0,000$.

Hasil penelitian ini sama dengan hasil penelitian Farisa (2012) di Depok tentang hubungan sikap, pengetahuan, ketersediaan dan keterpaparan media massa dengan konsumsi sayur dan buah pada siswa SMPN 8 Depok yang menunjukkan bahwa ada hubungan yang bermakna antara pengetahuan dengan konsumsi sayur dan buah pada remaja. Berbeda dengan hasil penelitian Wulansari (2009) di Bogor tentang konsumsi serta preferensi buah dan sayur pada remaja SMA dengan status sosial ekonomi yang berbeda yang menunjukkan bahwa tidak terdapat hubungan antara pengetahuan gizi dengan konsumsi sayur dan buah responden. Penelitian yang dilakukan Aswatini dkk (2008) di Lampung tentang konsumsi sayur dan buah di masyarakat dalam konteks pemenuhan gizi seimbang yang menunjukkan bahwa pengetahuan tidak berhubungan secara signifikan terhadap konsumsi sayur dan buah.

Pada penelitian ini, siswa SD cenderung memiliki pengetahuan sedang tentang sayur dan buah. Siswa mengetahui manfaat sayur dan buah tetapi tidak terlalu mengetahui dampak kurangnya sayur dan buah. Berdasarkan hasil penelitian ini bahwa tidak ada hubungan pengetahuan siswa terhadap konsumsi sayur dan buah karena terdapat faktor lain seperti kesukaan, ketersediaan di rumah sehingga pengetahuan responden yang baik belum tentu konsumsi sayur dan buahnya juga baik. Umumnya masyarakat mengetahui pentingnya konsumsi sayur dan buah untuk kesehatan, tetapi pemahaman yang mendalam masih kurang sehingga tidak menjadi dasar untuk konsumsi sayur dan buah juga baik sesuai anjuran.

Pengetahuan siswa mengenai manfaat dari sayur dan buah baik, tetapi pengetahuan siswa mengenai dampak kurangnya konsumsi sayur dan buah banyak yang menjawab salah sehingga untuk meningkatkan pengetahuan tersebut perlu lebih banyak sosialisasi dan pemaparan tentang berbagai dampak apabila kurang mengkonsumsi sayur dan buah terutama dari pihak sekolah, sehingga siswa mendapat wawasan dan dapat meningkatkan konsumsi terhadap sayur dan buah.

\section{Hubungan sikap dengan konsumsi sayur dan buah}

Sikap merupakan reaksi tertutup dari seseorang. Sikap dapat berubah jika terjadi perubahan komponen kognitif dan afektif. Hasil analisi penelitian menunjukkan bahwa sikap siswa terhadap sayur dan buah mempunyai hubungan yang signifikan dengan konsumsi sayur dan buah pada siswa SD Negeri 1 Rajabasa Raya yang ditunjukkan nilai $\mathrm{p}=0,000$. Hasil penelitian ini sejalan dengan penelitian Klepp et al (2005) di Eropa tentang promosi konsumsi buah dan sayur antara anak sekolah di Eropa yang menyatakan bahwa sikap merupakan faktor yang mempengaruhi konsumsi buah dan sayur pada remaja. Penelitian ini berbeda dengan penelitian Farisa (2012) di Depok tentang konsumsi sayur dan buah pada siswa SMPN 8 Depok yang menyatakan bahwa sikap tidak memiliki hubungan yang bermakna dengan konsumsi sayur dan buah. 
Sikap responden pada penelitian ini menunjukkan tentang pendapat responden yang setuju ataupun tidak setuju terhadap pertanyaan-pertanyaan tentang sayur dan buah. Sehingga dapat diketahui bahwa banyak responden yang setuju terhadap pertanyaan-pertanyaan mengenai sayur dan buah yang dilihat dari hasil analisis univariat yang menggambarkan responden dengan sikap baik presentasinya lebih banyak dibandingkan responden dengan kategori sikap kurang. Hal ini menunjukkan, bahwa responden banyak yang setuju terhadap konsumsi sayur dan buah. Namun, sikap yang baik belum tentu perilaku konsumsinya juga baik. Oleh karena itu, perlu ditanamkan motivasi agar sikap yang baik pada responden dapat merubah perilaku konsumsinya menjadi lebih baik.

\section{Simpulan dan saran}

Simpulan penelitian menunjukkan Faktor yang meningkatkan konsumsi buah dan sayur pada siswa Sekolah dasar adalah preferensi, pengetahuan yang baik, dan sikap yang mendukung. Perlunya upaya peningkatan pengetahuan siswa tentang manfaat dan dampak jika kurang konsumsi sayur dan buah, sehingga siswa mendapat lebih banyak wawasan tentang sayur dan buah dengan menggunakan media poster. Keluarga perlu menyiapkan sayur dan buah setiap hari dengan baik secara kuantitas dan kualitas yang baik dengan harga yang terjangkau oleh kemampuan keluarga.

\section{Referensi}

Akhmad, E.Y. (2011). Diet sehat untuk remaja. Yogyakarta: Yunius.

Almatsier., \& Sunita. (2011). Gizi seimbang dalam daur kehidupan. Jakarta: PT Gramedia Pustaka Utama.

Annema., Neeltje., Jane, S.H., Sarah, A., M. Barry, I., \& Lin, F. (2011). Fruit and Vegetable Consumption and Risk of Proximal Colon, Distal Colon, and Rectal Cancers in a case-Control Study in Western Australia. Journal of American Dietetic Association,111, 1479-1490.

Arisman. (2008). Buku Ajar Ilmu Gizi: Gizi Dalam Daur Kehidupan. Jakarta: Penerbit Buku Kedokteran EGC.

Astawan., Made., \& Andreas, L.K. (2008). Khasiat warna-warni makanan. Jakarta: PT. Gramadia Pustaka Utama.

Aswatini., Noveria, M., \& Fitranita. (2008). Konsumsi sayur dan buah di masyarakat dalam konteks pemenuhan gizi seimbang. Jurnal Kependudukan Indonesia Vol. III No.2.

Badan Penelitian dan Pengembangan Kesehatan. (2008). Laporan hasil riset kesehatan dasar Indonesia-tahun 2007. Jakarta: Kementerian Kesehatan RI.

Badan Pusat Statistik (BPS). (2013). Rata-rata konsumsi kalori (KKal) per kapita sehari menurut kelompok makanan 1999, 2002-2013.

Farida., Ida. (2007). Faktor-faktor yang berhubungan dengan perilaku konsumsi buah dan sayur pada remaja di Indonesia. Jakarta: Ilmu Kesehatan FK Skripsi. Universitas Islam Negeri.

Farisa., \& Soraya. (2012). Hubungan sikap, pengetahuan, ketersediaan dan keterpaparan media massa dengan konsumsi buah dan sayur pada siswa SMPN 8 Depok tahun 2012. Depok: Skripsi. Fakultas Kesehatan Masyarakat Universitas Indonesia.

Geissler, C., \& Hillary, P. (2010). Human nutrition (12th Edition). London: Elsevier Churchill Livingstone.

Hastono, S.P. (2001). Analisis Data, FKM, UI.

WHO., \& FAO. (2004). Join FAO/WHO Workshop On Fruit And Vegetable For Health. Kobe: Japan.

Khomsan., \& Ali. (2003). Pangan dan gizi untuk kesehatan. Jakarta: PT Raja Grafindo Persada.

Klepp., Knut, I., Carmen P.R., Ilse, D.B., Pernille, D., Ibrahim, E.D., Johanna, H., Jurgen, K., Michael, S., Inga, T., Maria, D.V.A., Agneta, Y., \& Johannes, B. (2005). Promoting Fruit And Vegetable Consumption Among European Schoolchildren: Rationale, Conceptualization and Design of the Pro Children Project. Annals of Nutrition and Metabolism, 49,212-220. 
Faktor-Faktor yang Berhubungan dengan Konsumsi Sayur dan Buah pada Siswa Sekolah Dasar Mindo Lupiana, Sadiman Sadiman

Jurnal Kesehatan Metro Sai Wawai. 10 (2) 2017. E-ISSN 2657-1390. P-ISSN 19779-469X

Sandvik, C., Ilse, D.B., Pernille, D., Johannes, B., Marianne, W., Elling, B., Carmen, P.R., Alexandra, W., Ibrahim, E., Inga, T., Maria, D.V.A., Agneta, Y., \& Knut, I.K. (2005). Personal, Social and Environmental Factors Regarding Fruit And Vegetable Intake Among School Children In Nine European Countries. Annals Of Nutrition Metabolism.

Wulansari., \& Natalia, D. (2009). Konsumsi serta preferensi buah dan sayur pada remaja SMA dengan status Bogor. Bogor: IPB 